\title{
Exploring the motivation and willingness of self-initiated expatriates, in the civil engineering industry, when considering employment opportunities in Qatar
}

This paper provides empirical and contextual insight into the complexity of Self-Initiated Expatriates' (SIEs) experiences in a unique setting. Factors that influence SIEs in the civil engineering industry, when considering overseas employment in Qatar, are identified and considered. Drawing comparison to organisational expatriates (OEs) and builds on the work of Doherty, Dickmann, and Mills (2011), this paper uses semistructured interviews conducted with professionals from the civil engineering and construction industries. The research surfaced that different factors interconnect to affect individuals' decisions about overseas employment. Three factors, specifically; location appeal, host country as an employment setting and effect of expatriation on family, appear to be more influential to participants when the proposed destination is Qatar. Keywords: Self-initiated expatriates; Qatar; global mobility; civil engineering

\section{Introduction}

Multinational enterprises (MNEs) entering emerging economies aim to identify and pursue opportunities for growth that are not obtainable in their home-country market (Peng 2014). Growth may be achieved through high yield, yet low risk, investment, manufacturing and production efficiencies, or the availability of better, technically capable people (Wright, Geroy, and Macphee 2000). Emerging markets, such as the Middle East, offer growth opportunities, but nevertheless produce difficulties for organisations due to high political risk and location sensitivities (Shubita 2015). Global expansion in project-driven industries, such as civil engineering, creates a reliance on Third Country Nationals (TCNs) (Welch, Welch, and Tahvanainen 2008) and international projects bring an added complexity, through the need to manage resources of varying duration across different locations (Gray 2013).

While research into the area of motives and international assignments has been previously conducted (Richardson and McKenna 2000; D. J. Jackson et al. 2005; Dickmann 
and Mills 2009; Thorn 2009; Selmer and Lauring 2012) there is insufficient research that addresses this topic expressly in the Middle East, and in the specific context of less traditional mobility patterns, such as Self-Initiated Expatriates (SIEs) (Andresen et al. 2014; Guttormsen 2016). This paper addresses the gap by presenting empirical research that contributes to our understanding of global mobility. This study contributes to knowledge by exploring how the motivation and willingness of SIEs to undertake career opportunities in a unique and specific geographic context is affected by an explicitly proposed destination. The key research questions addressed in this paper are:

Research question 1: What are the different factors that affect SIEs' considerations of overseas employment opportunities?

Research question 2: How does Qatar, as a proposed destination, influence the factors identified in RQ1?

Qatar provides a unique setting for this study, due to having the highest level of reliance on foreign workers in the world (Gulf Labour Markets and Migration 2017). Despite also being reported as having the world's highest gross domestic product based on purchasing-power-parity per capita (International Monetary Fund 2017), the reliance on such a large expatriate workforce has resulted in high unemployment among Qatari national youths and women (Lopez 2015). This reliance is currently being exacerbated by the region's significant investment into infrastructure and sporting facilities as it prepares to host the 2022 FIFA World Cup (Roscoe 2010). The impact to the local labour market as a result of the reliance on foreign workers may provide lessons for other countries that are reliant on foreign workers, such as other Gulf Cooperation Council (GCC) nations. Thus, exploring the different factors that affect SIEs' consideration of overseas employment opportunities in the context of Qatar is an important contribution of this paper. By exploring how different contextual factors affect individuals' international career decisions, this paper informs our 
understanding of human resource development practice by surfacing how sociocultural issues can either support or hinder global careers. Understanding the motivation and willingness behind international career decisions is important as our traditional notion of global mobility is challenged (Farndale et al. 2014; Guttormsen 2016). By developing our understanding, it can help to inform corporate human resource development practices and policy linked to attracting, developing and retaining SIEs.

The paper proceeds by presenting a review of the extant literature on SIEs' motivations and willingness to expatriate. The methods by which this study was undertaken and empirical context are explained, a discussion of the research findings explores the themes that emerged from the study, and conclusions and implications are then presented. Finally, limitations of this study are highlighted and suggestions for future research made.

This paper builds on the work of Doherty, Dickmann, and Mills (2011), their eightfactor model, summarised in Table 1, was used to measure the difference in reasons to expatriate between SIEs and Organisational Expatriates (OEs). Their findings suggest that factors relating to the location were more important to SIEs than OEs, the present paper takes this notion forward using Qatar as an explicit location to explore how other factors of the model are affected.

\section{Literature review}

SIEs are distinguished as those who choose to relocate overseas for work purposes on their own initiative, as opposed to being sent on an overseas assignment by their employers (OEs) (Suutari and Brewster 2000). The concept of SIEs has grown in academic significance over the past decade (Doherty 2013) and continues to evolve as the differences between OEs, SIEs and migrant workers are explored (Al Ariss and Crowley-Henry 2013; Andresen et al. 2014). In this paper, an SIE is defined as an individual who has pursued, or may consider pursuing, employment overseas on his or her own initiative. This definition allows for the inclusion of 
potential SIEs, as well as actual SIEs, reflecting the reality that organisations in Qatar need to attract candidates from external labour markets (Silvanto, Ryan, and McNulty 2015).

Although the traditional OE model remains the most expensive approach to international staffing (McNulty, De Cieri, and Hutchings 2009), global expansion drives a continuing reliance on an expatriate workforce. The emergence of SIEs as a recognised group has highlighted that there is an alternative talent pool from which organisations can recruit. Understanding what motivates SIEs to relocate overseas is particularly important for organisations operating in expatriate-reliant regions, such as the GCC (Bashir 2010). The reliance on SIEs in GCC countries is exacerbated by the fact that local employers do not have overseas subsidiaries from where staff can be sent to the region as OEs (Bashir 2010), reiterating the importance of understanding what motivates SIEs as opposed to OEs (Selmer and Lauring 2012).

Studies have investigated different factors that motivate SIEs to relocate overseas (Richardson and McKenna 2002; Glassock and Fee 2015) including; the desire for travel and adventure, career development, financial reward, and change of lifestyle. However, limited consideration has been given as to how the proposed geographical destination affects these factors.

Building on the work of Doherty, Dickmann, and Mills (2011), the present study contributes to knowledge by exploring how the motivating factors are influenced when the proposed host destination is Qatar. Their study was conducted through the analysis of 522 questionnaires of which $35 \%$ of participants were OEs and $65 \%$ were SIEs. Although the present research focuses solely on SIEs, the framework of Doherty, Dickmann, and Mills (2011) was chosen as their study suggested that 'Location and host reputation motives were significantly more important to the self-initiated suggesting that the desire to move to a particular country and characteristics of that country were primary drivers' (Doherty, 
Dickmann, and Mills 2011, 595). Whilst location and host country reputation were recognised as influencing factors, the present study has sought to further our understanding by investigating how an explicitly proposed destination affects the other factors.

\section{Location appeal}

Factors that make a destination appealing for OEs are considered from both professional and personal perspectives (Haslberger and Zehetner 2014). The importance that SIEs place on employment locations has been discussed, albeit not extensively, in the extant literature (Glassock and Fee 2015). The perception of a location's safety and culture are significant to individuals contemplating expatriate opportunities, as well as the language spoken in the host country (de Eccher and Duarte 2016). A significant difference highlighted between OEs and SIEs is that SIEs have more freedom to select host countries (Dickmann et al. 2016), which implies that they are more likely to relocate to destinations that they find attractive and safe (Muir, Wallace, and McMurray 2014). Perceptions of a location, however, are often based on media representation and word-of-mouth, highlighting a gap between pre-place and actual experience thus surfacing the need for effective location branding (Ceric and Crawford 2016). As Caligiuri and Bonache (2016) have cited, the location factors are an important research consideration, which this paper acknowledges by focusing on why some countries appear to be more challenging places to work.

\section{Host country as an employment setting}

Whereas the location appeal considers the attractiveness of a destination in terms of culture and living environment, the host factor reflects the location's attractiveness as an employment setting (Doherty, Dickmann, and Mills 2011). Institutionalised frameworks such as regulations relating to visa requirements may act as deterrents to particular locations (Muir, Wallace, and McMurray 2014). This consideration is exacerbated in the GCC as in 
most cases a woman is not able to provide visa sponsorship for her husband or children (Stalker and Mavin 2011). In the context of Brazil, von Borell de Araujo et al. (2013) noted that formalities such as residential leasing and accessing utilities could also prove challenging for SIEs. These formalities when coupled with pre-place experience of the place prior to arrival, such as being obtained through word-of-mouth (Ceric and Crawford 2016) could act as an important influencing factor in SIEs' decisions to pursue employment opportunities in a specific location.

The employment protection afforded by local employment frameworks, is also a consideration that may be more apparent for SIEs than OEs, as SIEs tend to be employed on local contracts whereas OEs typically maintain home country employment rights. In the GCC the situation is, again, further exacerbated as the governance of Shari'a law does not include provision for preventing discrimination (Metcalfe 2011). Further factors which play a role in the appeal of a host country as an employment setting include currency stability, taxation, and cost of living (IPM Global Mobility 2016).

\section{Career development and progression}

A distinguishing characteristic of SIEs is that they shape their own career paths and development opportunities beyond the boundaries of a location or organisation (Ceric and Crawford 2016). Makkonen (2016) suggests that careers are becoming more uncertain and argue that career self-management behaviour, as defined by Z. King (2004), is particularly important for SIEs as they do not have organisational support and instead rely on social networks (Richardson and McKenna 2014).

Although many organisations require international experience for senior level progression (Laroche and Bing 2016), Doherty, Dickmann, and Mills (2011) found that career enhancement was not the most significant motivating factor for SIEs but, rather, a component that was aligned to broader life plans. Career related issues, however, extended 
beyond career progression to encompass financial remuneration and professional development (Selmer and Lauring 2012) as an influencing factor in SIEs' relocation decisions. A recent study by Dickmann et al. (2016), which examined the Finnish labour market, suggests that SIEs' career capital increases due to overseas work experience. It is not clear, however, where participants were based and whether the host destination may have affected career capital. An alternative view suggests that accumulation of career capital is not the primary motivator of self-initiated expatriation, but rather a means by which foreign experience is achieved (Muir, Wallace, and McMurray 2014).

\section{Pursuit of international experience}

Seeking adventure and building personal confidence are drivers of pursuing international experience (Doherty, Dickmann, and Mills 2011). Altman and Baruch (2012) furthered earlier work (Useem and Karabel 1986; Baruch, Bell, and Gray 2005) to propose that international experience enhances expatriates' human capital in terms of knowledge, personal networks, cultural understanding, self-confidence and market value. Moreover, they suggest that expatriates' motivations have evolved over time and personal growth has become a primary driver for international experience. Froese (2012) suggests that international experience goes beyond seeking adventure, to experience life in a specific country, however, the desire to gain international experience is not as prevalent as previous studies have suggested.

Selmer and Lauring (2012) conducted a quantitative study with academics originating from 60 different countries, working in 35 universities in northern European countries. Their study suggests that respondents were motivated not only for work reasons, but also from a tourism perspective. Using metaphors to describe expatriates' motivation for relocation, as defined by Osland (1995) and Richardson and McKenna (2002), they identified the desire for adventure as a reason to relocate, synonymous with the Explorer metaphor. In a study 
exploring the role of social networks using a multi-method case study approach, Richardson and McKenna (2014) reported similar findings; that the pursuit of adventure was the reason to relocate for over half of all interview participants. Whilst both studies engaged with a diverse range of participants, it is not clear how the motivation and pursuit of adventure has been affected by the host destination. The present study offers a different point of exploration, by positioning the proposed destination as Qatar.

More recently, Glassock and Fee (2015) used a consumer decision-making model to deromanticize SIEs' draw to adventure, suggesting instead that SIEs are cautious about foreign relocation. The present paper reflects on these ideas to consider how Qatar as a proposed destination affects the desire to pursue international experience.

\section{Personal relationships}

Personal relationships encompass the opportunity to be with family, or maintain personal networks, achieved through self-initiated expatriation (Doherty, Dickmann, and Mills 2011). Roos (2013) highlighted the interconnectedness between pursuit of an international opportunity and personal relationships, such as joining a spouse already located overseas. An alternative perspective highlights that SIE experiences can have an adverse effect on personal relationships, due to the stress caused on SIEs and their immediate family members (Makkonen 2016).

Doherty, Dickmann, and Mills (2011) suggested that if an individual has previously had a positive work experience aboard, this became influential in their decision to pursue overseas employment. A positive work experience abroad can be assessed by the extent to which an expatriate adjusts to the environment cognitively, affectively and behaviourally (Haslberger, Brewster, and Hippler 2013). As cultural distance and time spent overseas affect expatriate adjustment (Hippler, Brewster, and Haslberger 2015) previous expatriate experience has been acknowledged as a factor which influences the decision to spend another 
period of time working and residing overseas (Glassock and Fee 2015), enhances the crosscultural adjustment of expatriates (Koveshnikov, Wechtler, and Dejoux 2014), and arguably may alter SIEs' perceptions of culturally distant destinations (Ceric and Crawford 2016). The degree of cultural distance and number of different expatriate experiences, however, do not appear to have been considered. To the contrary, research into OEs by de Eccher and Duarte (2016) found that previous international experience did not hold any influence over acceptance of future international assignment opportunities.

Despotovic, Hutchings, and Mcphail (2015) found that in situations where an SIE had a personal relationship with an individual from the host destination, participants reported that their preparation for relocation was improved. Their study also found that previous international experience was beneficial for future adjustment, regardless as to whether the previous experience was in a culturally similar, or, distant destination.

\section{Effect of expatriation on family}

How expatriation 'affects' family considers not only how family may be better supported through an overseas opportunity, but also that better opportunities may be available to them through international experience (Doherty, Dickmann, and Mills 2011). Benefits, therefore, can take many guises, for example, Selmer and Lauring (2012) drew on the Mercenary metaphor (Richardson and McKenna 2002) highlighting that a primary reason to relocate may be to support family financially. Furthermore, conditions relating to family were found to be one of the most influential factors for SIE academics, according to a study by Froese (2012), which reflects earlier studies (Richardson and Mallon 2005; Richardson 2006).

The experience of relocating internationally is as challenging for SIEs as it is for their families (Vaiman, Haslberger, and Vance 2015). When considering different cultural contexts the impact to family is more important (Guo and Al Ariss 2015), reinforcing the criticality of organisation-provided support to ensure successful employment of SIEs (Selmer 
and Lauring 2011). As family structures become more diverse and complex, this calls for organisations to provide more personalised assistance (Caligiuri and Bonache 2016).

More recently, research has surfaced the influence of extended, multi-generational family ties on international relocation decisions (Clark and Altman 2015). Moreover, SIEs' decisions are influenced by their spouses' career and the respective availability of work, as well as the impact on their children's education (Ceric and Crawford 2016). Families have long been cited as a primary reason for OE failure (Cole and Nesbeth 2014), particularly in culturally distant host countries (D. Jackson and Manderscheid 2015). To date, whether the affect is similar for SIEs remains unclear.

\section{Home-host country relations}

Home-host country relations consider the extent to which it is desirable to SIEs to remain in the host country (Doherty, Dickmann, and Mills 2011) and the parallel allegiance to their home country (Henry 2013). Allegiance to the host country is affected by how SIEs perceive the support from their employing organisation (Cao, Hirschi, and Deller 2014); their loyalties often becoming torn between their home and host countries (Lo et al. 2012). Allegiance to host country can be developed through ties and networking opportunities, which SIEs are understood to use, to help facilitate access to overseas employment opportunities (Richardson and McKenna 2014).

Alternative perspectives of home-host country relations consider how the cultural and physical distance between home and host nations affects relocation decisions (Alshahrani and Morley 2015). The greater the physical, cultural, or even, economic distance, the less likely SIEs may be to consider the proposed location (de Eccher and Duarte 2016). The cultural distance between UK and Qatar, for example, is manifested through employment relations in Qatar including a religious dimension beyond any formal contracts, whereas Western employment is technically and materially governed (Branine and Pollard 2010). There is a 
lack of contemporary literature relating to SIEs and home-host country relations, thus the literature featuring expatriates sent on overseas assignments by their employers has been drawn upon.

\section{Push factors}

Push factors may reflect challenges securing home country employment, or a way in which individuals may physically distance themselves from a problem (Doherty, Dickmann, and Mills 2011). Makkonen (2016) identified that a keen motivation for expatriation appeared to be linked to poor labour market opportunities in the home country. Push factors cause overlap when distinguishing between SIEs and migrant workers, as the motivation to relocate corresponds to necessity, rather than desire (Al Ariss 2010).

Considering push factors beyond those that solely affect SIEs, Martin (2003) identified three influencing factors, demand, supply and network; each from an economic and non-economic perspective. Factors include high unemployment or low wages, thus implying that nationals of these countries are likely to seek overseas employment opportunities (Somerville and Cooper 2009; Andresen, Biemann, and Pattie 2015). Awad and Abimourced (2009) suggest that the deficit of work opportunities acts as a push factor which encourages the pursuit of overseas employment. Indirect occurrences may also have an impact on the economic pull factors, Awad and Abimourced (2009) suggest that demographic changes, such as a shrinking population, lead to a need to maintain economic activity and become pull factors attracting foreign workers. Economic pull factors are heavily characterised by the destination, despite this (and as previously considered by Dickmann and Mills [2009] and Doherty, Dickmann, and Mills [2011]), very little of the extant expatriate literature considers the extent to which location influences expatriates' decisions to pursue overseas employment. A primary contribution of this study addresses this issue by positioning Qatar as a proposed destination 


\section{Methods and Context}

This paper explores the motivation and willingness of SIEs when considering overseas employment opportunities in Qatar. The aim of the paper is to identify the different factors that affect SIEs' consideration of overseas employment opportunities and to understand how the proposed destination influenced these factors, specifically when the proposed destination is Qatar.

This study is grounded in an interpretivist epistemology as the intention is to provide rich and in-depth insights into the issues at hand. Thus the research aimed to engage with participants in order to understand their perceptions and understanding, through a qualitative approach. Similar to other studies (Scurry, Rodriguez, and Bailouni, 2013; Makkonen 2016) using a qualitative methodology, semi-structured interviews were undertaken to enable the investigation of key topic areas while still allowing flexibility (Aurini, Heath, and Howells 2016). Interviews were conducted at a mutually convenient time and location either face-toface, or using a voice-over-internet protocol (Iacono, Symonds, and Brown 2016). Interviews enabled the capture of participants' beliefs and experiences, in their own words, and were deemed an appropriate mechanism for data collection.

Adopting a synergistic theoretical position, this study contributes to extant knowledge by expanding our understanding in a new context (Ridder, Hoon, and McCandless Baluch 2014). In 2010, it was announced that Qatar's bid to host the 2022 FIFA World Cup had been successful. Consequently, over the eleven years leading up to it, it has been anticipated that at least 100 billion US dollars will be invested into the region's infrastructure and sporting facilities (Roscoe 2010). Such massive investment in development programmes is likely to continue to see a boom in the Qatari construction market with both global and local firms in the industry battling for market shares (Senouci, Al-Abbadi, and Eldin 2015). The growth will create opportunities for increased employment of Qatari nationals, whilst also 
continuing to attract highly qualified expatriates to the region. It is recognised that there are not enough academically qualified or experienced Qatari nationals to meet the rapidly growing requirements (Berrebi, Martorell, and Tanner 2009; Ennis 2015) and that the attraction and retention of skilled expatriates is therefore crucial to the country's success.

Qatar has the highest number of foreign workers in the world; the estimated number of foreign workers grew from $80.5 \%$ of the population in 2005 to $86.5 \%$ in 2010 (Awad, Wickramasekara, and Taran 2010) and in 2016 reflected $89.9 \%$ of the population (Gulf Labour Markets and Migration 2017). Despite a strong economic position, the reliance on such a large expatriate workforce has resulted in high unemployment among Qatari national youths and women (Lopez 2015).

The civil engineering industry produces physical structures which are not mobile, thus requiring resource to mobilise to the site of construction (Fellini, Ferro, and Fullin 2007). Further complexity is caused as construction often occurs where there is minimal established infrastructure, adding the constraints of isolated and sometimes dangerous locations. Rapid growth in the global market thus increases the need for expatriate workers, often to so-called hardship destinations (Meyskens et al. 2009). The Qatari construction market will continue to grow (Al-Ghorairi 2012) and the subsequent influx of expatriate workers has significant implications for private sector organisations employing SIEs.

The research was conducted using a purposive sampling approach. Purposive sampling allowed participants to be selected as their characteristics were relevant to the aims of the study (Saunders 2012). Although purposive sampling does not always provide a 'typical' sample, the purpose of the study was not to generalise but rather to highlight emergent themes (Jankowicz 2000).

At the point of data collection, the first author had been employed in a senior HR position, within the civil engineering industry for over ten years, which helped to secure 
interview participants for the research. The participants worked in a professional capacity within the construction and civil engineering industries and were approached directly through the first author's professional network; participants were either already known first-hand by the first author or referred by colleagues.

To meet the criteria for inclusion, participants had to have been employed within a professional capacity, holding either a higher academic qualification or having an established skilled trade, within the construction industry. As the study sought to explore how factors affecting motivation and willingness to relocate overseas changed when the proposed destination was Qatar, participants could not be currently, or have been recently, located in Qatar. Individuals who had not previously undertaken overseas employment were also included as they form a talent pool from which international organisations recruit.

The interview guide covered three core areas for discussion: participants' perception and feelings towards his or her home country, participants' perceptions and feelings towards working and residing overseas; and, participants' perceptions about Qatar. Three pilot interviews were conducted and, as all three proved successful, the content was included in the final analysis. Following the pilot, minor adjustments to the sequence of topics in the interview guide were made but the overall structure was not changed. An example of how Doherty, Dickmann, and Mills' (2011) eight factor model and its respective items align to the interview guide is shown in Table 2, which portrays the foreign experience factor as a specific example.

All participants signed an informed consent form prior to the interview taking place. Table 3 provides a breakdown of the participants' details and demonstrates the diversity of the sample. The status column depicts if the participant is married, in a relationship or single and the number of children they have. The country of residence refers to the country in which the participant resided at the time of the interview. 
The interviews were audio-recorded and then transcribed; participants were provided an opportunity to review and annotate the transcriptions. The data from the interviews were coded using Dedoose software and analysed using N. King's (2004) template analysis method. Initially, a coding template of a priori codes was produced and was then further developed iteratively through further analysis, review of the literature and interpretation (Srivastava and Hopwood 2009). Figure 1 provides an example of the data structure and coding. The data structure portrays the progression from the initial codes to emergent themes (Gioia, Corley, and Hamilton 2012).

\section{Findings and Discussion}

The findings expand on the eight-factor model of Doherty, Dickmann, and Mills (2011), each factor forms a subheading within the findings, followed by a final section which focuses on issues arising which specifically pertain to Qatar. Verbatim excerpts from the semistructured interviews are used to illustrate how the findings either reflect, or provide alternative perspectives to the extant literature.

\section{Location appeal}

As previously discussed, location factors explain a location's appeal to an SIE based on the attractiveness as a place of residence (Doherty, Dickmann, and Mills 2011). Within this factor, three themes were emergent relating to participants' consideration of a location's infrastructure; living standards, climate, and local language. The perceived standards of living provided a critical consideration:

...the standard of living where you live which is appropriate for family, schools and school expense, this is very important... (Adnan)

There is a level of interconnectedness with the effect of expatriation on the family as the participant is considering location factors not just for himself but how his family may, or may not, benefit from the experience. The importance of this factor reflects the work of Glassock 
and Fee (2015) and also reiterates the importance of organisations providing support for SIEs and their families (Selmer and Lauring, 2011).

The appeal of a warmer climate emerged in some participant interviews, however, it did not appear to be a critical factor, rather something that was aspirational, as one participant expressed:

... no matter what time of the year it is, go to work in daylight, finish in daylight ... a nice warm atmosphere... (Ivan)

The third theme, language was much more perceptible with participants who did not have previous foreign experience, reflecting the work of de Eccher and Duarte (2016).

... the scariest thing I think of going abroad is first of all the language barrier and are you going to cope with it... (Ivan)

This finding contrasts Selmer and Lauring's (2011) suggestion that the requirement to speak another language, for native English speakers, may actually be motivation to relocate from a personal development perspective.

\section{Host country as an employment setting}

The host country factor considers the employment perspective of an overseas location (Doherty, Dickmann, and Mills 2011). The most prominent theme relating to this factor related to institutionalised frameworks.

Participants expressed concern about the dependency on employment visas; this was particularly apparent with participants who had foreign experience gained in a GCC member state as residency is explicitly linked to employment.

... your work is related to your visa so when you finish your work you have to be careful if your visa is cancelled... (Adnan)

In this case, there is interconnectedness with push factors as a visa cancellation would result in the participant being forced to return to Syria. At the time of the interview, this was a push factor for him to remain overseas due to conflict in the home region. Interconnectedness was also emergent with the effect of expatriation on the family, again relating to visas. In the next 
excerpt, the participant considers not only his own visa status from a host perspective, but also whether his family will benefit.

... if they grant visas for my family, they consider that then I'm happy to work there... (Muhsin)

\section{Career development and progression}

Career related issues encompass an individual's perception of the benefit of international experience to their career, both financially and professionally (Selmer and Lauring 2012). Three sub-themes emerged relating to the ability to save money and how the international experience could have both beneficial and detrimental effects.

In agreement with Selmer and Lauring (2012), a participant explains how the ability to save financially has been a motivating reason to relocate overseas.

... the reason why we moved out was to save cash and get a nest egg behind us so we could live a bit more comfortable [sic] if we went back to the UK ... (David)

The next two excerpts are from the same participant's interview and show that firstly, overseas experience can have a positive career impact, reflecting the work of (Dickmann et al. 2016) and that overseas work experience increases career capital.

... a few years on your CV of working abroad is just good experience ... it shows that you're willing to be a bit more open-minded about things ... (David)

However, too long spent overseas can permanently label an individual as an expatriate, potentially preventing future career opportunity, highlighting Makkonen's (2016) argument that SIEs require career self-management.

...just be mindful how long you spend out of the UK because if you spend too long out of the UK you then get earmarked as an expat ... there's a stigma to people who have spent ... years abroad and then come back to the UK... (David)

The excerpt offers an alternative view that international experience may actually be detrimental to future career progression, which could be a reason to deter SIEs from further international opportunities. 


\section{Pursuit of international experience}

As discussed, pursuit of international experience encapsulates the desire for adventure but also to experience living in a particular country (Froese 2012). Personal growth, as a theme, surfaced from the interviews in relation to international experience. One participant provided a useful description of what personal growth means to her:

... confidence, knowledge, capabilities built up in different ways, just opening up your mind to new stuff and wider networks, I think I made a more rounded person ... and what's happening here when actually there's so much more going on in the world ... I like change and I like new experiences... (Carly)

The focus for international experience has been on individuals originating from so-called developed nations travelling to developing nations. It was highlighted in the interviews that the desire for international experience was also important for individuals from diverse backgrounds, which is reflective of the suggestion by Selmer and Lauring (2011) that foreign experience is potentially more apparent for non-EU nationals relocating to the EU, than the other way around.

\section{Personal relationships}

The personal network facet of personal relationships (Doherty, Dickmann, and Mills 2011) was a notable sub-theme which was manifested through participants' previous international commuting experience and has more recently been noted as a means through which SIEs attain international opportunities (Richardson and McKenna 2014). One participant shared her story about a requirement in a previous role to frequently commute internationally and how this helped her when she relocated permanently.

\footnotetext{
...I would commute... between France and Romania and later on ... between Belgium and Romania on a monthly basis, so I'd spend half of my time back home and half of my time in one of these other places and I think it helps me in a way adapt better to moving abroad... (Rosanne)
}

This closely reflects the work of Glassock and Fee (2015) in that previous international experience influences the decision to relocate overseas and also supports the 
adjustment process (Koveshnikov, Wechtler, and Dejoux 2014). The following excerpt shows how previous international experience has facilitated consideration of different destinations.

...I have travelled quite a lot through my life anyway ... I would probably go and work anywhere now ... (Carly)

Another participant explained the reason for her relocation and that although for work purposes, it was also to be closer to a loved one; highlighting the link between overseas employment and personal relationships (Roos 2013).

...I moved to Dubai mainly for personal reasons I was in a long distance relationship with someone who was living in Dubai and we wanted to give it a chance... (Rosanne)

\section{Effect of expatriation on the family}

An interconnectedness between the effect of expatriation on the family and pursuit of international experience emerged, as depicted in the following reflection:

....she said coming out here has made her a different person ... it's had a positive effect on my life, it's changed me in a good way ... more tolerant, open minded ... (David)

This is an interesting finding and reflects Doherty's (2013) view that the potential for learning opportunities for family members can be a reason to relocate internationally. The participant's comment exemplifies how he has perceived, and reflected with his wife, how she benefitted from their time spent living in Dubai.

The interviews surfaced that family members who remained in the home country were also perceived to have benefitted from the SIE's overseas work. For example, the following excerpt shows how one participant was able to fund the education of his siblings as a result of his overseas experience.

my father ... can [not] manage to educate my other brothers, that's why I've taken that responsibility on my shoulders... (Muhsin)

\section{Home-host country relations}

Home-host country relations consider the extent to which participants prefer to remain overseas (Doherty, Dickmann, and Mills 2011) and, in parallel, allegiance to their home 
country (Henry 2013). Surprisingly, in contrast to the work of Richardson and McKenna (2006) there were limited findings relating to home-host country relations which were raised by the participants. The most notable comment related to home country attachment:

...I wasn't so attached to my home country in the first place... I would say it's still my home country but I don't feel the need to go back very soon... (Rosanne)

This suggests that the lack of home country allegiance may have been an influencing factor for considering overseas employment in the first place.

\section{Push factors}

Push factors are conceptualised from two primary perspectives; firstly home-country instability driving the need for overseas employment and, secondly, the desire to distance oneself from a problem (Doherty, Dickmann, and Mills 2011). Problem avoidance was very apparent for two participants who originated from Syria. In both cases an initial motivation to seek overseas employment was to avoid undertaking compulsory military service.

... as per our let's say military laws you have to serve the country for another two-and-ahalf years in military services which is basically [sic], you'll be wasting your time... (Fahad)

Unfortunately, the recent conflict arising in Syria has manifested into a reason preventing their repatriation to Syria, thus the initial reason for pursuing overseas employment has changed over time.

...we just want this war to finish, we want peace, everything to settle down, [the] economy there is damaged completely now... years are passing and still I am unable to go back ... (Adnan)

These findings problematize how destination can affect the factors that influence SIEs' overseas relocation decisions. By understanding how these factors influence SIEs' decisions, organisations can adapt and shape policies and provide relevant information to mitigate factors which may act as a deterrent based on location. 


\section{Qatar as a proposed destination}

The research sought to understand how the factors identified by Doherty, Dickmann, and Mills (2011) changed if the proposed overseas destination was Qatar. While each factor was affected by Qatar as a proposed destination, the impact varied. In some cases Qatar as a location had an adverse effect on the factor in question, for example; when considering family instead of recognising potential benefits, participants expressed apprehension about how local infrastructure may prohibit family adjustment.

When Qatar was suggested as an employment destination, specific concerns were expressed relating to the local infrastructure, particularly regarding the quality of education and health care. Additionally, while a warm climate is generally appealing, in Qatar, it was perceived to be too hot.

The volume of construction projects was a unique and attractive host factor; participants appeared well informed of the construction growth, presumably due to media coverage of Qatar's plans of hosting the 2022 FIFA World Cup. Surprisingly, despite the volume and diversity of construction projects, potential professional development and career progression were not raised as motivating factors. Individuals who had worked in the GCC region were notably more informed about the nature of specific projects. The strict visa restrictions, however, proved to be a deterrent for participants:

... particularly appealing in Qatar is right now they are totally booming, there is lots of projects over there especially for us working in the construction area... (Gregorio)

The influence of other factors, identified by Doherty, Dickmann, and Mills (2011), career development and progression, pursuit of international experience, home-host country relations and push factors did not change when Qatar was the proposed destination.

Interestingly, religion was not raised in relation to Qatar; due to the range of participants, it was anticipated that religion might be raised although no direct questions were 
asked to incite this topic. One explanation may be that the business world is considered a “religion neutral sphere" (Mellahi and Budhwar 2010, 685).

In response to the initial research questions, the study has shown that destination plays an important role and affects different factors when individuals consider overseas employment. Three factors; location appeal, host country as an employment setting and effect of expatriation on family, were most notably different when the proposed destination was Qatar. The other factors did not change in their appeal to participants. It is surprising that in light of the volume of construction projects that career development and progression did not emerge as a more prominent factor for individuals working within the industry.

\section{Conclusion and Implications}

The purpose of this research has been to explore individuals' thoughts and experiences to determine factors that organisations in the civil engineering industry should consider when seeking to employ SIEs in Qatar. This study contributes to knowledge by exploring how the motivation and willingness of SIEs' to pursue international employment is affected by an explicitly proposed geographic setting. The findings have been presented by building upon the work of Doherty, Dickmann, and Mills (2011), this approach has highlighted that there is a high level of interconnectedness between the different factors and, as such, factors influence each other and are thus not mutually exclusive. Furthermore, the nuance between willingness and motivation has been surfaced. Table 4 depicts how the findings from this study align to Doherty, Dickmann, and Mills' (2011) eight factor model and suggests that these factors can affect SIEs' motivation and willingness differently. Factors relating to motivation call on a desire for achievement or avoidance through international employment. The factors relating to willingness, however, speaks to a more intrinsic desire to relocate overseas for its own sake. 
This research has further informed our understanding of SIEs, from a human resource development perspective, by surfacing how sociocultural factors can overshadow career development and progression opportunities. As global expansion continues, it is important that our knowledge of why people relocate internationally and the part that destination plays in this decision is deepened. This is even more critical for expatriate-reliant regions, such as Qatar.

Employers in Qatar can overcome concerns expressed by SIEs by taking several steps to increase the transparency of employment realities in the region. Concerns about infrastructure such as education and healthcare may be addressed by developing partnerships with local schools and making critical education information more readily available to potential SIEs. Similarly, the healthcare provision should be a transparent part of the benefits package and information about healthcare facilities proactively communicated to potential SIEs to allow them to take more informed decisions. The issue of visa reliance could be addressed by making the processes clear to potential SIEs, and developing internal policies detailing support which could be provided post-employment.

\section{Limitations}

At the time of this study commencing, Qatar had recently been awarded the right to host the 2022 World Cup. In the succeeding few years FIFA's decision has been challenged in light of allegations of corruption. While the decision may be revoked in the future, this research remains valid as its inductive nature reflects the opinions of the participants at the point at which the study was undertaken.

The diverse nationalities of participants are an asset of this study, but they are also a weakness as so many more nationalities have not been included, which may have elicited different findings. It is also acknowledged that while a variety of participants from different 
nationalities were included, a disproportionate number of participants were British. As this is a qualitative study, however, it was not the objective to generalise the findings across nationalities.

All women interviewed were single; this study did not consider females in a family and 'bread-winner' role or males as trailing spouses. If the demographic of participants was different, this would likely impact on the overall findings. The fact that female breadwinners or male trailing spouses did not emerge as part of the demographics is in itself an interesting finding in that there might not be many instances of these family arrangements.

\section{Future Research}

As Qatar's development continues on the journey to 2022 to host the FIFA World Cup, other industries, such as hospitality, will begin to grow in the region. It would be interesting to learn if the findings from this research resonate with individuals from different occupational backgrounds. Future research may also consider how the findings from this study and the implications to local labour markets may be applicable and provide lessons for other nations that are reliant on foreign workers, such as those within the GCC.

This study has surfaced the nuance between willingness and motivation, however, there is currently limited empirical research which explores these perspectives in the context of expatriate's pursuit of overseas employment opportunities, and this presents an opportunity for a future research direction.

\section{References}

Al-Ghorairi, Abdulaziz. 2012. “Qatar Construction Sector.” Doha, Qatar. http://www.cbq.qa. Al Ariss, Akram. 2010. "Modes of Engagement: Migration, Self-Initiated Expatriation, and Career Development." Career Development International 15 (4): 338-58. doi:10.1108/13620431011066231.

Al Ariss, Akram, and Marian Crowley-Henry. 2013. "Self-Initiated Expatriation and 
Migration in the Management Literature: Present Theorizations and Future Research Directions." Career Development International 18 (1): 78-96. doi:10.1108/13620431311305962.

Alshahrani, Saeed Turki, and Michael J Morley. 2015. "Accounting for Variations in the Patterns of Mobility among Conventional and Self-Initiated Expatriates." International Journal of Human Resource Management 26 (15): 1936-54. doi:10.1080/09585192.2015.1041757.

Altman, Yochanan, and Yehuda Baruch. 2012. "Global Self-Initiated Corporate Expatriate Careers: A New Era in International Assignments?" Personnel Review 41 (2): 233-55. doi:10.1108/00483481211200051.

Andresen, Maike, Franziska Bergdolt, Jil Margenfeld, and Michael Dickmann. 2014. "Addressing International Mobility Confusion - Developing Definitions and Differentiations for Self-Initiated and Assigned Expatriates as Well as Migrants." The International Journal of Human Resource Management 25 (16): 2295-2318. doi:10.1080/09585192.2013.877058.

Andresen, Maike, Torsten Biemann, and Marshall Wilson Pattie. 2015. "What Makes Them Move Abroad? Reviewing and Exploring Differences between Self-Initiated and Assigned Expatriation." The International Journal of Human Resource Management 26 (7): 932-47. doi:10.1080/09585192.2012.669780.

Aurini, Janice, Melanie Heath, and Stephanie Howells. 2016. The How to of Qualitative Research. London: SAGE Publications Ltd.

Awad, Ibrahim, and Rola Abimourced. 2009. "International Labour Migration and Employment in the Arab Region:" International Labour Migration and Employment in the Arab Region, 1-29. http://www.ilo.org/wcmsp5/groups/public/---arabstates/---robeirut/documents/meetingdocument/wcms_208699.pdf.

Awad, Ibrahim, Piyasri Wickramasekara, and Patric Taran. 2010. "International Labour Migration: A Rights-Based Approach." Generva. http://digitalcommons.ilr.cornell.edu/cgi/viewcontent.cgi?article=1086\&context=intl.

Baruch, Yehuda, Myrtle P. Bell, and David Gray. 2005. "Generalist and Specialist Graduate Business Degrees: Tangible and Intangible Value.” Journal of Vocational Behavior 67 (1 SPEC. ISS.): 51-68. doi:10.1016/j.jvb.2003.06.002.

Bashir, R. 2010. "Wanted: A National Labor Force.” A Middle East Point of View. Vol. November. http://www.deloitte.com/view/en_US/us/index.htm.

Berrebi, Claude, Francisco Martorell, and Jeffery C. Jefferey C. Tanner. 2009. "Qatar's Labor Markets at a Crucial Crossroad.” The Middle East Journal 63 (3): 421-42. doi:10.3751/63.3.14.

Branine, Mohamed, and David Pollard. 2010. "Human Resource Management with Islamic Management Principles.” Personnel Review 39 (6): 712-27. doi:10.1108/00483481011075576.

Caligiuri, Paula, and Jaime Bonache. 2016. "Evolving and Enduring Challenges in Global Mobility." Journal of World Business 51 (1). Elsevier Inc.: 127-41. doi:10.1016/j.jwb.2015.10.001.

Cao, Lan, Andreas Hirschi, and Jürgen Deller. 2014. "Perceived Organizational Support and 
Intention to Stay in Host Countries among Self-Initiated Expatriates: The Role of Career Satisfaction and Networks." The International Journal of Human Resource Management 25 (14): 2013-32. doi:10.1080/09585192.2013.870290.

Ceric, Arnela, and Heather J. Crawford. 2016. "Attracting SIEs: Influence of SIE Motivation on Their Location and Employer Decisions." Human Resource Management Review 26 (2). Elsevier Inc.: 136-48. doi:10.1016/j.hrmr.2015.10.001.

Clark, David, and Yochanan Altman. 2015. "In the Age of 'liquid Modernity': Self-Initiated Expatriates in Crete, Their Multi-Generational Families and the Community." The International Journal of Human Resource Management 5192 (January): 1-15. doi:10.1080/09585192.2015.1079230.

Cole, Nina, and Kimberly Nesbeth. 2014. "Why Do International Assignments Fail? The Expatriate Families Speak." International Studies of Management and Organization 44 (3): 1-17. doi:10.2753/IMO0020-8825440304.

de Eccher, Umberto, and Henrique Duarte. 2016. "How Images about Emerging Economies Influence the Willingness to Accept Expatriate Assignments." The International Journal of Human Resource Management 5192 (April): 1-27. doi:10.1080/09585192.2016.1172653.

Despotovic, William Vuk, Kate Hutchings, and Ruth Mcphail. 2015. "Cross-Cultural SelfPreparation of Australian Self-Initiated Expatriates for Working and Living in South Korea: 'Stumped like a Bonsai: A Show of What Could Have Been.'" Asia Pacific Journal of Human Resources 53 (2): 241-59. doi:10.1111/1744-7941.12035.

Dickmann, Michael, and Timothy Mills. 2009. "The Importance of Intelligent Career and Location Considerations: Exploring the Decision to Go to London." Personnel Review 39 (1): 116-34. doi:10.1108/00483481011007896.

Dickmann, Michael, Vesa Suutari, Chris Brewster, Liisa Mäkelä, Jussi Tanskanen, and Christelle Tornikoski. 2016. "The Career Competencies of Self-Initiated and Assigned Expatriates: Assessing the Development of Career Capital over Time." The International Journal of Human Resource Management, 1-25. doi:10.1080/09585192.2016.1172657.

Doherty, Noeleen. 2013. "Understanding the Self-Initiated Expatriate: A Review and Directions for Future Research.” International Journal of Management Reviews 15 (4): 447-69. doi:10.1111/ijmr.12005.

Doherty, Noeleen, Michael Dickmann, and Timothy Mills. 2011. "Exploring the Motives of Company-Backed and Self-Initiated Expatriates." The International Journal of Human Resource Management 22 (3): 595-611. doi:10.1080/09585192.2011.543637.

Ennis, Crystal A. 2015. "Between Trend and Necessity: Top-down Entrepreneurship Promotion in Oman and Qatar." Muslim World 105 (1): 116-38. doi:10.1111/muwo.12083.

Farndale, Elaine, Avinash Pai, Paul Sparrow, and Hugh Scullion. 2014. "Balancing Individual and Organizational Goals in Global Talent Management : A Mutual- Benefits Perspective." Journal Of World Business 49 (January): 204-14. doi:10.1016/j.jwb.2013.11.004.

Fellini, I., a. Ferro, and G. Fullin. 2007. "Recruitment Processes and Labour Mobility: The 
Construction Industry in Europe.” Work, Employment \& Society 21 (2): 277-98. doi:10.1177/0950017007076635.

Froese, Fabian Jintae. 2012. "Motivation and Adjustment of Self-Initiated Expatriates: The Case of Expatriate Academics in South Korea." The International Journal of Human Resource Management 23 (6): 1095-1112. doi:10.1080/09585192.2011.561220.

Gioia, Dennis a., Kevin G. Corley, and A. L. Hamilton. 2012. "Seeking Qualitative Rigor in Inductive Research: Notes on the Gioia Methodology." Organizational Research Methods 16 (1): 15-31. doi:10.1177/1094428112452151.

Glassock, Gabriela, and Anthony Fee. 2015. "The Decision-Making Processes of SelfInitiated Expatriates: A Consumer Behaviour Approach.” Journal of Global Mobility 3 (1): 4-24. doi:http://dx.doi.org/10.1108/02683940010305270.

Gray, Lloyd. 2013. "The Depth Metaphor and International Human Resource Development: From Theory to Practice." Human Resource Development International 16 (October): 426-40. doi:10.1080/13678868.2013.801629.

Gulf Labour Markets and Migration. 2017. "GCC: Total Population and Percentage of Nationals and Foreign Nationals in GCC Countries." Gulf Labour Markets and Migration. http://gulfmigration.eu/gcc-total-population-percentage-nationals-foreignnationals-gcc-countries-national-statistics-2010-2016-numbers/?print=pdf.

Guo, Chun, and Akram Al Ariss. 2015. "Human Resource Management of International Migrants: Current Theories and Future Research." The International Journal of Human Resource Management 26 (10): 1287-97. doi:10.1080/09585192.2015.1011844.

Guttormsen, David S. A. 2016. “Introducing the Expatriate 'Entry-Mode': An Exploratory Qualitative Study of a Missing Link in Global Mobility and Expatriate Management Research." Human Resource Development International 0 (0). Routledge: 1-28. doi:10.1080/13678868.2016.1240288.

Haslberger, Arno, Chris Brewster, and Thomas Hippler. 2013. "The Dimensions of Expatriate Adjustment." Human Resource Management 52 (3): 333-51. doi:10.1002/hrm.21531.

Haslberger, Arno, and Karl Zehetner. 2014. "Cosmopolitan Appeal: What Makes a City Attractive to Expatriates." International Journal of Arts \& Sciences 7 (4): 509-23.

Henry, Jacques. 2013. "Return or Relocate? An Inductive Analysis of Decision-Making in a Disaster.” Disasters 37 (2): 293-316. doi:10.1111/j.1467-7717.2012.01303.x.

Hippler, Thomas, Chris Brewster, and Arno Haslberger. 2015. "The Elephant in the Room: The Role of Time in Expatriate Adjustment." International Journal of Human Resource Management 26 (June): 1920-35. doi:10.1080/09585192.2015.1041762.

Iacono, Valeria Lo, Paul Symonds, and David H K Brown. 2016. "Skype as a Tool for Qualitative Research Interviews." Sociological Research Online 21 (2). doi:10.5153/sro.3952.

International Monetary Fund. 2017. "World Ecomonic Outlook Database." http://www.imf.org/external/pubs/ft/weo/2017/01/weodata/download.aspx.

IPM Global Mobility. 2016. "Managing Exchange Rates for Your International Assignments." http://www.iprmglobalmobility.com. 
Jackson, Derrick, and Steven V Manderscheid. 2015. "A Phenomenological Study of Western Expatriates' Adjustment to Saudi Arabia." Human Resource Development International 18 (2). Routledge: 131-52. doi:10.1080/13678868.2015.1026552.

Jackson, Duncan J, Stuart C Carr, Margot Edwards, Kaye Thorn, Nicola Allfree, Jill Hooks, and Kerr Inkson. 2005. "Exploring the Dynamics of New Zealand's Talent Flow." New Zealand Journal of Psychology 34 (2): 110-16.

http://ovidsp.ovid.com/ovidweb.cgi?T=JS\&CSC $=Y \& N E W S=N \& P A G E=$ fulltext $\& D=p s$ yc4\&AN=2005-12109-006\%5Cnhttp://x-port-

sfx.uio.no/sfx_ubo?sid=OVID:psycdb\&id=pmid:\&id=doi:\&issn=0112-

$109 \mathrm{X} \&$ isbn $=\&$ volume $=34 \&$ issue $=2 \&$ spage $=110 \&$ pages $=110$ -

$116 \&$ date $=2005 \&$ title $=$ New + Zealand + Jo.

Jankowicz, A. 2000. Business Research Projects. 3rd ed. London: Thomson Learning. doi:186152-549-4.

King, Nigel. 2004. "Using Templates in the Thematic Analysis of Text." In Essential Guide to Qualitative Methods in Organizational Research, edited by Catherine Cassell and Gillian Symon, 256-70. London: SAGE Publications Ltd.

King, Zella. 2004. "Career Self-Management: Its Nature, Causes and Consequences." Journal of Vocational Behavior 65 (1): 112-33. doi:10.1016/S0001-8791(03)00052-6.

Koveshnikov, Alexei, Heidi Wechtler, and Cecile Dejoux. 2014. "Cross-Cultural Adjustment of Expatriates: The Role of Emotional Intelligence and Gender." Journal of World Business 49 (3). Elsevier Inc.: 362-71. doi:10.1016/j.jwb.2013.07.001.

Laroche, Lionel, and Catherine Mercer Bing. 2016. "Negotiating Expatriate Packages.” ITAP International. http://www.itapintl.com/index.php/about-us/articles/negotiatingexpatriate-packages.

Lo, Ka In Helena, IpKin Anthony Wong, C. M. Richard Yam, and Richard Whitfield. 2012. "Examining the Impacts of Community and Organization Embeddedness on SelfInitiated Expatriates: The Moderating Role of Expatriate-Dominated Private Sector." The International Journal of Human Resource Management 23 (20): 4211-30. doi:10.1080/09585192.2012.665075.

Lopez, Sandra. 2015. "Women in the Workforce: Moving beyond Higher Education in Qatar." In Public Diplomacy \& Global Policymaking in the 21st Century, edited by Kristian Coates and Ariana Marnicio, 57-60. Doha, Qatar: Rice University's Baker Institute for Public Policy. http://bakerinstitute.org/media/files/files/5d29305d/PDGPpub-QatarReport-110215.pdf\#page=28.

Makkonen, Paula. 2016. "Career Self-Management Behaviour of Western Self-Initiated Expatriates in Local Organizations in China." The International Journal of Human Resource Management 27 (11): 1135-57. doi:10.1080/09585192.2015.1061580.

Martin, Philip L. 2003. "Managing International Labor Migration in the 21st Century." South-Eastern Europe Journal of Economics, 9-18.

McNulty, Yvonne, Helen De Cieri, and Kate Hutchings. 2009. "Do Global Firms Measure Expatriate Return on Investment? An Empirical Examination of Measures, Barriers and Variables Influencing Global Staffing Practices." The International Journal of Human Resource Management 20 (6): 1309-26. doi:10.1080/09585190902909830. 
Mellahi, Kamel, and Pawan S. Budhwar. 2010. "Introduction: Islam and Human Resource Management.” Personnel Review 39 (6): 685-91. doi:10.1108/00483481011075558.

Metcalfe, Beverly Dawn. 2011. "Women, Empowerment and Development in Arab Gulf States: A Critical Appraisal of Governance, Culture and National Human Resource Development (HRD) Frameworks." Human Resource Development International 14 (2): 131-48. doi:10.1080/13678868.2011.558310.

Meyskens, Moriah, Mary Ann Von Glinow, William B. Werther, Jr, and Linda Clarke. 2009. "The Paradox of International Talent: Alternative Forms of International Assignments." The International Journal of Human Resource Management 20 (6): 1439-50. doi:10.1080/09585190902909988.

Muir, Melinda, Michelle Wallace, and Don McMurray. 2014. "Women on the Move: The Self-Initiated Expatriate in China.” Journal of Global Mobility 2 (2): 234-54. doi:10.1108/JGM-06-2013-0045.

Osland, Joyce. 1995. The Adventure of Working Abroad. San Francisco, CA: Jossey-Bass Publishers.

Peng, Mike W. 2014. Global Business. 4th ed. Boston, MA: Cengage.

Pinto, Luísa H, Carlos Cabral-Cardoso, and William B. Werther. 2012. "Compelled to Go Abroad? Motives and Outcomes of International Assignments." The International Journal of Human Resource Management 23 (11): 2295-2314. doi:10.1080/09585192.2011.610951.

Richardson, Julia. 2006. "Self-Directed Expatriation: Family Matters." Personnel Review 35 (4): 469-86. doi:10.1108/00483480610670616.

Richardson, Julia, and Mary Mallon. 2005. "Career Interrupted? The Case of the SelfDirected Expatriate." Journal of World Business 40 (4): 409-20. doi:10.1016/j.jwb.2005.08.008.

Richardson, Julia, and Stephen McKenna. 2000. "Metaphorical " Types and Human Resource Management : Self- Selecting Expatriates." Industrial and Commercial Training 32 (6): 209-19.

Richardson, Julia, and Stephen McKenna. 2002. "Leaving and Experiencing: Why Academics Expatriate and How They Experience Expatriation." Career Development International 7 (2): 67-78. doi:10.1108/13620430210421614.

Richardson, Julia, and Stephen McKenna. 2006. "Exploring Relationships with Home and Host Countries: A Study of Self-Directed Expatriates." Cross Cultural Management: An International Journal 13 (1): 6-22. doi:10.1108/13527600610643448.

Richardson, Julia, and Stephen McKenna. 2014. "Towards an Understanding of Social Networks among Organizational Self-Initiated Expatriates: A Qualitative Case Study of a Professional Services Firm." The International Journal of Human Resource Management 25 (19): 2627-43. doi:10.1080/09585192.2014.884614.

Ridder, Hans Gerd, Christina Hoon, and Alina McCandless Baluch. 2014. "Entering a Dialogue: Positioning Case Study Findings towards Theory." British Journal of Management 25 (2): 373-87. doi:10.1111/1467-8551.12000.

Rodriguez, Jenny K., and Tracy Scurry. 2014. "Career Capital Development of Self-Initiated 
Expatriates in Qatar: Cosmopolitan Globetrotters, Experts and Outsiders." The International Journal of Human Resource Management 25 (2): 190-211. doi:10.1080/09585192.2013.815254.

Roos, Hannelore. 2013. "In the Rhythm of the Global Market: Female Expatriates and Mobile Careers: A Case Study of Indian ICT Professionals on the Move." Gender, Work and Organization 20 (2): 147-57. doi:10.1111/gwao.12016.

Roscoe, Andrew. 2010. "Kicking off Qatar â€ $€^{\mathrm{TM}}$ S Football Dream." MEED: Middle East Economic Digest 54 (50): 22-23. http://search.ebscohost.com/login.aspx? direct $=$ true $\& \mathrm{db}=\mathrm{bth} \& \mathrm{AN}=56675652 \&$ site $=$ ehost?live.

Saunders, Mark N K. 2012. "Choosing Research Participants.” In Qualitative Organizational Research, edited by Gillian Symon and Catherine Cassell, 35-52. London: SAGE Publications Ltd.

Selmer, Jan, and Jakob Lauring. 2011. "Acquired Demographics and Reasons to Relocate among Self-Initiated Expatriates." The International Journal of Human Resource Management 22 (10): 2055-70. doi:10.1080/09585192.2011.580176.

Selmer, Jan, and Jakob Lauring. 2012. "Reasons to Expatriate and Work Outcomes of SelfInitiated Expatriates." Personnel Review 41 (5): 665-84. doi:10.1108/00483481211249166.

Senouci, Ahmed, Ibrahim Al-Abbadi, and Neil Eldin. 2015. "Safety Improvement on Building Construction Sites in Qatar." Procedia Engineering 123. Elsevier B.V.: 504-9. doi:10.1016/j.proeng.2015.10.102.

Shubita, Moade Fawzi. 2015. "The Impact of Income Smoothing on Earnings Quality in Emerging Markets: Evidence from GCC Markets." Journal of Accounting in Emerging Economies 5 (3): 299-324. doi:10.1108/JAEE-04-2011-0011.

Silvanto, Sari, Jason Ryan, and Yvonne McNulty. 2015. "An Empirical Study of Nation Branding for Attracting Internationally Mobile Skilled Professionals." Career Development International 20 (3): 238-58. doi:10.1108/CDI-08-2014-0105.

Somerville, Will, and Betsy Cooper. 2009. "Immigration to the United Kingdom." Immigration Worldwide: Policies, Practices and Trends.

Srivastava, Prachi, and Nick Hopwood. 2009. "A Practical Iterative Framework for Qualitative Data Analysis.” International Journal of Qualitative Methods 8 (1): 76-84. doi:file://C:/Users/emma.keller/Downloads/1169-13435-1-PB\%20(1).pdf.

Stalker, B., and S. Mavin. 2011. "Learning and Development Experiences of Self-Initiated Expatriate Women in the United Arab Emirates." Human Resource Development International 14 (3): 273-90. doi:10.1080/13678868.2011.585062.

Suutari, Vesa, and C Brewster. 2000. "Making Their Own Way: International Experience through Self-Initiated Foreign Assignments." Journal of World Business 20 (4): 417-36. doi:10.1016/S1090-9516(00)00046-8.

Thorn, Kaye. 2009. "The Relative Importance of Motives for International Self-Initiated Mobility." Career Development International 14 (5): 441-64.

Useem, Michael, and Jerome Karabel. 1986. "Pathways to Top Corporate Management." American Sociological Review 51 (2): 184-200. doi:10.2307/2095515. 
Vaiman, Vlad, Arno Haslberger, and Charles M. Vance. 2015. "Recognizing the Important Role of Self-Initiated Expatriates in Effective Global Talent Management." Human Resource Management Review 25 (3). Elsevier Inc.: 280-86. doi:10.1016/j.hrmr.2015.04.004.

von Borell de Araujo, Bruno Felix, Maria Luisa Mendes Teixeira, Poliano Bastos da Cruz, and Elise Malini. 2013. "Understanding the Adaptation of Organisational and SelfInitiated Expatriates in the Context of Brazilian Culture." The International Journal of Human Resource Management 25 (18): 2489-2509. doi:10.1080/09585192.2012.743470.

Welch, Catherine, Denice Welch, and Marja Tahvanainen. 2008. "Managing the HR Dimension of International Project Operations." The International Journal of Human Resource Management 19 (2): 205-22. doi:10.1080/09585190701799754.

Wright, Phillip C, Gary D Geroy, and Maura Macphee. 2000. "A Human Resources Model for Excellence in Global Organization Performance." Management Decision 38 (1): 3642. doi:10.1108/00251740010311816. 
Table 1: Eight Factors Driving Expatriation (Doherty, Dickmann and Mills 2011)

\begin{tabular}{|c|c|}
\hline Factors Driving Expatriation & Description of Factor \\
\hline Location Factor & $\begin{array}{l}\text { Host country appeal in terms of culture and } \\
\text { perceived standard of living. }\end{array}$ \\
\hline Host Factor & $\begin{array}{l}\text { Host country appeal in terms of an employment } \\
\text { destination, including accessibility and reputation. }\end{array}$ \\
\hline Career-Related Factor & $\begin{array}{l}\text { Perceived career development offered from the } \\
\text { international experience. }\end{array}$ \\
\hline Foreign Experience Factor & $\begin{array}{l}\text { Opportunity for adventure and to develop personal } \\
\text { skills related to international travel. }\end{array}$ \\
\hline Personal Relationships Factor & $\begin{array}{l}\text { Effect of previous international experience and use } \\
\text { of personal network. }\end{array}$ \\
\hline Family Factor & $\begin{array}{l}\text { Impact to family members and their adjustment by } \\
\text { relocating internationally. }\end{array}$ \\
\hline Home-Host Relations Factor & $\begin{array}{l}\text { Balancing the allegiance to home country and } \\
\text { preference to remain in the host country. }\end{array}$ \\
\hline Push Factor & $\begin{array}{l}\text { Conditions in the home country leading to } \\
\text { individuals seeking overseas employment. }\end{array}$ \\
\hline
\end{tabular}


Table 2: Alignment between eight factor model (Doherty, Dickmann and Mills 2011) and interview guide

\section{Factor Driving Expatriation $\quad$ Interview Guide}

Desire for adventure

What do you think the effect would be for you

To see the world

The opportunity to improve personally?

your language skills

What are your thoughts about working overseas?

What appeals to you? What deters you?

Confidence in your ability to work/live abroad

What are you experiences working overseas?

Professional challenge of working abroad

How would the experience influence your career? 
Table 3: Participants' Gender, Nationality and Family Status

\begin{tabular}{llllc}
\hline Pseudonym & Gender & Nationality & Marital status & $\begin{array}{c}\text { No. } \\
\text { children }\end{array}$ \\
\hline Allen & Male & British & Married & 2 \\
Carly & Female & British & Single & 0 \\
Tim & Male & British & In a relationship & 1 \\
David & Male & British & Married & 3 \\
Tony & Male & British & Single & 0 \\
Fahad & Male & Syrian & Single & 0 \\
Rosanne & Female & Romanian & Single & 0 \\
Adnan & Male & Syrian & Married & 2 \\
Chelsey & Female & British & In a relationship & 0 \\
Safah & Female & Palestinian* & Single & 0 \\
Muhsin & Male & Indian & Married & 2 \\
Gregorio & Male & Filipino & Married & 2 \\
Rebecca & Female & British & Single & 0 \\
Noah & Male & Filipino & Married & 2 \\
Niral & Male & Indian & Married & 1 \\
Ivan & Male & British & In a relationship & 0 \\
Travis & Male & British & Married & 1 \\
\hline
\end{tabular}

* Safah considers her home country to be Jordan 
Table 4: Findings depicted by motivation and willingness

\begin{tabular}{lll}
\hline $\begin{array}{l}\text { Factors Driving Expatriation } \\
\text { (Doherty, Dickmann and Mills }\end{array}$ & Motivation & Willingness \\
\hline Location Factor & $\begin{array}{l}\text { Climate } \\
\text { Infrastructure } \\
\text { Language }\end{array}$ & \\
Host Factor & $\begin{array}{l}\text { Institutionalized } \\
\text { frameworks }\end{array}$ & \\
Career-Related Factor & $\begin{array}{l}\text { Financial benefit } \\
\text { Professional } \\
\text { development }\end{array}$ & \\
Foreign Experience Factor & Personal growth \\
Personal Relationship Factor & Personal networks \\
Family Factor & $\begin{array}{l}\text { Effect on family } \\
\text { Home-Host Relations Factor }\end{array}$ & $\begin{array}{l}\text { Home country } \\
\text { allegiance }\end{array}$ \\
Push Factor & instability & \\
& & \\
\hline
\end{tabular}


Figure 1: Data structure

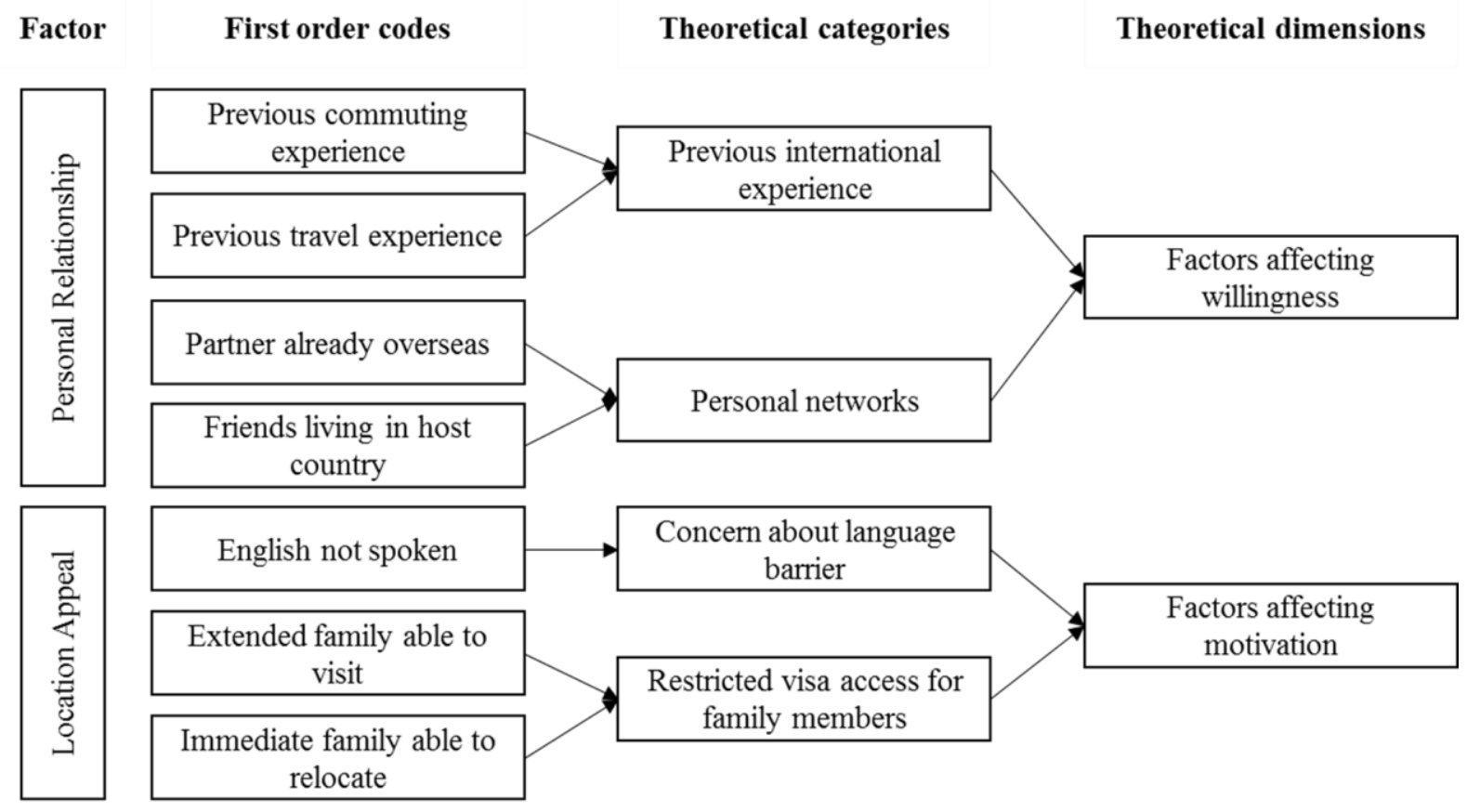

